\title{
ANALISIS PENGARUH KEBIJAKAN DIVIDEN DAN UKURAN PERUSAHAAN TERHADAP LEVERAGE PERUSAHAAN DENGAN INVESTMENT OPPORTUNITY SET (IOS) SEBAGAI VARIABEL MODERASI PADA SEKTOR TRADE, SERVICES \& INVESTMENT YANG TERDAFTAR DI BEI
}

\author{
Yakobus Novritwo Sigalingging, Aminar Sutra Dewi \\ Sekolah Tinggi Ilmu Ekonomi KBP \\ sigalinggingyackobus123@gmail.com
}

\begin{abstract}
In the year 2017 there is a decrease in buying interest of the community, can be seen from the declining growth rate of business sub-sector that is retail company. This study aims to test empirically analysis of the effect of dividend policy and firm size on corporate leverage with investment opportunity set (IOS) as a moderation variable. The sample is done by using purposive sampling method. The data used are secondary data in the form of financial statement data from the retail industry sub-sector (retail trade) from 20142016. The result of this research shows that dividend policy has negative and insignificant effect to company leverage, firm size has negative and significant effect to company leverage. While using Moderated Regression Analysis (MRA) indicates that Investment Opportunity Set (IOS) have positive and insignificant effect to company leverage and Investment Opportunity Set (IOS) also have positive and insignificant effect to company leverage.
\end{abstract}

Keywords: Dividend Policy, Company Size, Investment Opportunity Set (IOS) and Corporate Leverage.

\section{PENDAHULUAN}

Industri manufaktur memiliki peranan yang begitu penting dalam sistem perekonomian Indonesia. Perkembangan industri manufaktur saat ini telah menciptakan suatu persaingan yang tajam antar perusahaan industri manufaktur. Situasi perkembangan ekonomi yang meningkat mendorong manajemen perusahaan agar dapat bekerja lebih efektif dan efisien agar dapat mempertahankan kestabilan perusahaan serta menjaga kelangsungan hidup pada persaingan perekonomian bisnis yang begitu ketat terutama pada perusahaan go publik di pasar modal (Astuti \& Efni, 2015).

Ketersediaan dana yang cukup untuk membiayai aktivitas operasional merupakan salah satu faktor yang penting bagi perusahaan, dikarenakan persaingan industri yang semakin ketat akan menjadi faktor penghambat keberlangsungan hidup sebuah perusahaan serta peluang untuk berkembang bagi 
perusahaan tersebut. Pendanaan tersebut bisa didapat dari internal dan eksternal perusahaan. (Masruroh, Nursanti, \& Lisa, 2011).

Leverage adalah suatu kemampuan yang dimiliki perusahaan dalam memenuhi likuiditas jangka pendek dan likuiditas jangka panjang atau bisa diukur dengan sejauh mana perusahaan didanai oleh sumber eksternal perusahaan yaitu hutang. Tujuan perusahaan dalam penggunaan Leverage yaitu supaya keuntungan yang didapat melebihi biaya aset dan sumber dana lainnya, oleh sebab itu akan meningkatkan dividen. (Novari \& Lestari, 2016).

Pada tahun 2017 terjadi penurunan minat beli masyarakat, dapat dilihat dari menurunnya tingkat pertumbuhan sub sektor bisnis yaitu perusahaan ritel. Kondisi perusahaan ritel (retail) di saat ini sudah 2,5 tahun underperformance, yang membuat situasi perusahaan ritel di Indonesia dalam situasi atau kondisi tidak meyakinkan. Dampak yang akan terjadi dalam perusahaan ritel (retail trade) jika daya beli turun secara terus menerus maka industri ritel akan mengalami penurunan tingkat penjualan, yang mana data yang tercatat pada BAPPENAS menunjukan bahwa pertumbuhan penjualan ritel riil dari 16,3 persen pada Juni 2016, anjlok menjadi 6,7 persen di Juni 2017, semantara hutang terus bertambah. Dengan ini kesulitan perusahaan dalam melunasi hutang-hutangnya akan terjadi adapun dampak lainnya maka minat investor akan berkurang. (Liputan6, 2017)

Pada dasarnya perusahaan juga melaksanakan aktivitas operasionalnya yang tak terlepas dari kewajiban dalam membayar dividen guna memberikan balas jasa kepada investor. Kebijakan dividen adalah keputusan dalam menentukan berapa besar bagian dari pendapatan yang diperoleh perusahaan yang akan diberikan kepada para pemegang saham yang diinvestasikan atau ditahan di dalam perusahaan (Larasati, 2011).

Ukuran perusahaan dapat berpengaruh terhadap mudahnya perusahaan untuk memperoleh hutang. Perusahaan besar memiliki total aktiva yang dominan lebih besar dan dapat dijaminkan dalam sumber pendanaan. Hal ini memungkinkan bahwa ukuran perusahaan berpengaruh terhadap akses perusahaan untuk memperoleh sejumlah dana. Kebijakan hutang dapat digunakan untuk mencapai nilai perusahaan yang diinginkan, tetapi kebijakan hutang tergantung dari ukuran perusahaan. Hal ini menunjukkan bahwa sebuah perusahaan yang besar relative akan lebih mudah untuk mengakses ke pasar modal. Hal ini mengindikasikan bahwa perusahaan dengan aktiva besar akan relatif mudah memenuhi sumber dana dari hutang melalui pasar modal (Nuraina, 2012)

Purnami dan artini (2016) mengatakan bahwa Investment Opportunity Set (IOS) adalah suatu kombinasi antara aktiva yang dimiliki dan pilihan-pilihan investasi dimasa yang akan datang dengan net present value positif. IOS dapat digunakan sebagai pilihan investasi saat ini dan diharapkan akan menghasilkan keuntungan yang lebih banyak di masa yang akan datang. Keuntungan yang dihasilkan dalam bentuk return. Bagi perusahaan yang tidak dapat menggunakan kesempatan investasi tersebut akan mengalami suatu pengeluaran yang lebih tinggi dibandingkan dengan nilai kesempatan yang hilang (Astuti \& Efni, 2015).

Dalam penelitian yang dilakukan oleh Kennedy. R. Fitrios dan R. Fitri (2009) tentang Pengaruh Dividen, Aliran Kas Bebas, Ukuran Perusahaan, Profitabilitas dan Risiko Terhadap Leverage Perusahaan Dengan Investment 
Opportunity Set (IOS) Sebagai Variabel Moderating menemukan bahwa IOS tidak mempengaruhi hubungan antara kebijakan dividen dengan Leverage perusahaan. Hasil penelitian ini menunjukkan hal yang berbeda dari penelitian sebelumnya yang dilakukan oleh Masruroh, dkk (2011) tentang Analisis Pengaruh Moderating Investment Opportunity Set Dengan Kebijakan Dividend Serta Moderating Investment Opportunity Set Dengan Arus Kas Bebas Terhadap Tingkat Leverage Perusahaan bahwa IOS mempengaruhi hubungan antara kebijakan dividen dengan Leverage perusahaan dimana IOS mempengaruhi hubungan antara kebijakan dividen dengan Leverage perusahaan.

Keputusan pendanaan berkaitan dengan pemilihan sumber dana baik berasal dari internal perusahaan maupun eksternal perusahaan, akan sangat mempengaruhi perusahaan. Sumber dana yang berasal dari sumber internal perusahaan adalah laba ditahan sedangkan dana yang berasal dari eksternal perusahaan adalah dana yang berasal dari kreditur dan peserta atau pengambil bagian di dalam perusahaan. Arieska \& Gunawan (2009) mengatakan dalam melaksanakan fungsi pemenuhan kebutuhan dana dan fungsi pendanaan, manajer keuangan selalu mencari alternatif-alternatif sumber dana untuk kemudian dianalisa untuk memutuskan langkah terbaik dalam pendanaan perusahaan.. Dalam penelitian yang dilakukan oleh Susanto (2011) kebijakan dividen berpengaruh terhadap kebijakan hutang. Kebijakan dividen yang stabil menyebabkan adanya keharusan bagi perusahaan untuk menyediakan sejumlah dana guna membayar jumlah dividen yang ditetapkan tersebut. Hasil yang berbeda dilakukan oleh Djabid (2009) menemukan bahwa kebijakan dividen perpengaruh positif dan tidak signifikan terhadap kebijakan utang. Maka dapat disimpulkan bahwa hipotesis pertama diduga kebijakan dividen berpengaruh positif dan signifikan terhadap Leverage Perusahaan.

Perusahaan besar ataupun kecil dapat terlihat melalui seberapa banyak perusahaan memiliki total aktiva. Suwardika \& Mustanda (2017) berpendapat bahwa perusahaan yang memiliki ukuran semakin besar akan membuat seorang investor menaruh perhatian yang besar pada perusahaan tersebut. Kondisi tersebut dapat terjadi karena perusahaan besar cenderung mempunyai kondisi yang semakin baik. Dalam penelitian yang dilakukan oleh Moh. Syadeli (2013) menemukan bahwa ukuran perusahaan berpengaruh terhadap Leverage perusahaanyang berarti semakin besar ukuran perusahaan, mengakibatkan peningkatan penggunaan hutang. Hasil yang sama juga ditemukan oleh Nuraina (2012) bahwa ukuran perusahaan juga berpengaruh terhadap Leverage perusahaan. Maka dapat disimpulkan bahwa hipotesis kedua diduga ukuran perusahaan berpengaruh negatif dan signifikan terhadap Leverage perusahaan.

Kebijakan dividen berkaitan dengan keputusan mengenai seberapa besar laba perusahaan akan dibagikan kepada pemegang saham atau menahannya untuk diinvestasikan kembali ke dalam perusahaan. Apabila dividen yang dibayarkan secara tunai semakin tinggi, maka dana yang tersedia untuk reinvestasi akan semakin rendah. Investment Opportunity Set (IOS) tinggi juga mencerminkan tingginya risiko yang harus ditanggung oleh lender sehingga menyebabkan cost of equity. Oleh karena itu tinggi rendahnya Investment Opportunity Set (IOS) dapat menentukan kuatnya hubungan antara dividen dengan Leverage prusahaan, karena 
Investment Opportunity Set (IOS) dapat mempengaruhi cost of debt bagi perusahaan dan kemakmuran perusahaan untuk akses kepenyediaan dana (Kennedy, Fitrios, \& Fitri, 2009).

Dari hasil penelitian yang dilakukan oleh Masruroh, dkk (2011) menemukan bahwa IOS mempengaruhi hubungan antara kebijakan dividen dengan Leverage perusahaan sedangkan Kennedy, Fitrios, \& Fitri (2009) menemukan hasil yang sama bahwa IOS juga tidak mempengaruhi hubungan antara kebijakan dividen dengan Leverage perusahaan. Maka dapat disimpulkan bahwa hipotesis ketiga diduga kebijakan dividen berpengaruh positif dan signifikan terhadap Leverage perusahaan dengan Investment Opportunity Set (IOS) sebagai variabel moderasi.

Nuraina (2012) mengatakan bahwa perusahaan besar dapat dengan mudah mengakses ke pasar modal. Kemudahan untuk mengakses ke pasar modal berarti perusahaan memiliki fleksibilitas dan kemampuan untuk mendapatkan dana, karena kemudahan aksebilitas ke pasar modal dan kemapuannya untuk memunculkan dana lebih besar. Dalam penelitian yang dilakukan Kennedy, dkk (2009) tentang Pengaruh Dividen, Aliran Kas Bebas, Ukuran Perusahaan, Profitabilitas Dan Risiko Terhadap Leverage Perusahaan Dengan Investment Opportunity Set (IOS) Sebagai Variabel Moderasi menemukan bahwa IOS tidak mempengaruhi hubungan antara Ukuran Perusahaan dengan Leverage perusahaan. Hasil yang sama juga ditemukan oleh Rofniati (2007) tentang Analisis Moderasi Investment Opportunity Set (IOS) Terhadap Hubungan Antara Dividen, Aliran Kas Bebas, Ukuran Perusahaan dan Profitabilitas Dengan Tingkat Leverage Perusahaan bahwa IOS tidak mempengaruhi hubungan antara Ukuran Perusahaan dengan Leverage perusahaan. Maka dapat disimpulkan bahwa hipotesis keempat diduga Ukuran Perusahaan berpengaruh positif dan tidak signifikan terhadap Leverage perusahaan dengan Investment Opportunity Set (IOS) sebagai variabel moderasi.

\section{METODE PENELITIAN}

Jenis penelitian dalam proposal yang saya ajukan ini adalah kuantitatif yaitu data yang berupa angka-angka(Novari, 2016). Data kuantitatif adalah data yang berbentuk angka atau data kualitatif yang diangkakan (Sugiyono, 2015). Data kuantitatif dalam penelitian ini digunakan dan dikembangkan dalam model matematis yang akan memunculkan hipotesis.

Objek dalam penelitian ini adalah sektor Trade, Services dan Investment yang terdaftar di Bursa Efek Indonesia (BEI). Bursa Efek Indonesia merupakan tempat yang tepat dan akurat mengenai informasi perusahaan-perusahaan yang telah Go Public.

Populasi adalah wilayah generalisasi yang terdiri atas objek atau subjek yang mempunyai kuantitas dan karakteristik tertentu yang diterapkan oleh peneliti untuk dipelajari dan kemudia ditarik kesimpulannya (Sugiyono, 2015). Populasi dalam penelitian ini adalah industri sub sektor ritel (retail trade) yang terdaftar di Bursa Efek Indonesia (BEI) pada tahun 2014-2016 sebanyak 23 perusahaan.

Sampel adalah bagian dari jumlah dan karakteristik yang dimiliki oleh populasi (Sugiyono, 2015). Sampel yang digunakan ditentukan dengan metode 
purposive sampling yaitu penentuan sampel dengan terlebih dahulu menentukan kriteria-kriteria yang diinginkan dari sampel(Larasati, 2011). Beberapa kriteria dalam pemilihan sampel adalah:

1. Perusahaan yang dipilih dalam bentuk sub sektor industri ritel (retail trade) yang tercatat di Bursa Efek Indonesia (BEI) selama tahun 20142016.

2. Tersedia data laporan keuangan selama kurun waktu penelitian periode berakhir 31 Desember.

3. Perusahaan yang menyediakan data mengenai variabel-variabel yang digunakan dalam penelitian ini selama periode 2014-2016.

Jumlah sampel industri ritel (retail trade) yang memenuhi kriteria adalah sebanyak 15 perusahaan.

Penelitian ini menggunakan jenis data sekunder berupa data laporan keuangan dari sub sektor industri ritel (retail trade) yang dijadikan sebagai sampel selama periode tahun 2014-2016. Menurut Indriantoro (1999) dalam Kennedy, dkk (2009), data sekunder adalah penelitian arsip (archival research) yang memuatkejadian masa lalu (historis).Data bersumber dari website Bursa Efek Indonesia (BEI) www.idx.co.id.

Dalam penelitian ini, metode pengambilan data yang digunakan adalah dengan metode dokumentasi karena datanya berupa data sekunder. Metode dokumentasi adalah suatu metode yang mempelajari catatan-catatan maupun dokumen yang berbentuk laporan keuangan perusahaan yang telah diaudit.

\section{a. Teknik Analisis Data}

\section{Analisis Statistik Deskriptif}

Statistik deskiptif adalah statistik yang berfungsi untuk mendeskripsikan atau memberi gambaran terhadap objek yang diteliti melalui data sampel atau populasi sebgaimana adanya, tanpa melakukan analisis dan membuat kesimpulan yang berlaku untuk umum (Novari, 2016)

\section{Uji Asumsi Klasik}

Ada tiga asumsi yang terpenting sebagai syarat penggunaan metode. Asumsi klasik tersebut adalah asumsi normalitas, Multikolinearitas, dan heterokedastisitas.

\section{Uji Normalitas}

Uji normalitas bertujuan untuk mengetahui apakah dalam model regresi, variable pengganggu atau residual memiliki distribusi normal (Masruroh, Nursanti, \& Lisa, 2011). Apabila hasil uji normalitas dengan Kolmogorov-Smirnov, diketahui bahwa nilai signifikansi lebih besar dari Alpha $(>0,05)$, sehingga dapat dikatakan bahwa data terdistribusi secara normal dan asumsi normalitas telah terpenuhi dan sebaliknya apabila nilai signifikansi lebih kecil dari aplha $(<0,05)$ maka data tidak terdistribusi secara normal.

\section{Uji Multikolinearitas}

Uji multikolinearitas adalah pengujian dari asumsi untuk membuktikan bahwa variabel-variabel bebas dalam suatu model tidak saling berkorelasi satu dengan yang lainnya. Adanya multikolinearitas 
dapat menyebabkan model regresi yang diperoleh tidak valid untuk menaksir variabel independen (Purnami \& Artini, 2016). Untuk mendeteksi ada atau tidaknya multikolinieritas di dalam model regresi dapat dilihat dari nilai tolerance dan variance inflation factor (VIF). Nilai cut-off yang umum dipakai untuk menunjukkan adanya multikolinieritas adalah nilai tolerance $>0,10$ atau sama dengan nilai VIF $<10$.

\section{Uji heteroskidastisitas}

Uji heteroskedastistas bertujuan menguji apakah dalam model regresiterjadi ketidaksamaan varian dari residual satu pengamatan kepengamatan lain. Model regresi yang baik adalah homokedastisitas, atau tidak terjadi heteroskedastisitas. (Purnami \& Artini, 2016). Untuk melihat ada atau tidaknya heteroskedastisitas dapat dilakukan dengan uji Glejser. Dalam uji ini apabila signifikasinya diatas tingkat kepercayaan 5\% (0,05).

\section{b. Analisis Regresi dengan Variabel Moderasi}

Analisis regresi linear dengan variabel moderasi ini, digunakan untuk melihat hubungan antara sebuah variabel dependen (tidak bebas) dengan dua atau lebih variabel independen (bebas) pada tahap I (satu). Sedangkan pada tahap II (dua), analisis linear dengan variabel moderasi digunakan dalam melihat pengaruh moderasi dalam mempengaruhi hubungan antara variabel independen terhadap variabel dependen.Adapun persamaan dalam penelitian ini adalah :

1. Analisis Regresi Tahap I $\mathrm{Y}=\alpha+\beta_{1} \mathrm{X}_{1}+\beta_{2} \mathrm{X}_{2}+\mathrm{e}$

2. Analisis Regresi Tahap II

$$
Y=\alpha+\beta_{1} X_{1}+\beta_{2} X_{2}+\beta_{3} X_{1} * Z+\beta_{4} X_{2} * Z+e
$$

\section{c. Uji Hpotesis}

\section{Uji F(Uji Simultan)}

Uji $F$ digunakan untuk mengetahui apakah independent variable (secara bersama-sama) berpengaruh secara signifikan atau tidak terhadap dependent variable. Bila signifikan berpengaruh berarti model yang diuji adalah model yang baik dipakai dalam penyederhanaan dunia nyata.(Masruroh et al., 2011)

\section{Uji Parsial (Uji t)}

Uji T digunakan untuk mengetahui pengaruh independent variable secara individu terhadap dependent variable.(Masruroh et al., 2011). Pengujian dilakukan dengan menggunakan significance level 0,05 $(\alpha=5 \%)$. Dimana penerimaan dan penolakan hipotesis dilakukan dengan kriteria jika nilai signifikansi $\left(t_{\text {hitung }}>t_{\text {tabel }}\right)$ atau $\alpha<0,05$ maka hipotesis ditolak dan sebaliknya, jika signifikansi $\left(t_{\text {hitung }}<t_{\text {tabel }}\right)$ atau $\alpha>0,05$ maka hipotesis ditolak.

\section{Uji R-Square (Koefisien Determinasi)}

Nilai Adjusted R-Square yang semakin mendekati 1 (satu) menunjukkan semakin kuat kemampuan variabel independen dalam menjelaskan variabel dependen. Apabila nilai Adjusted R-Square sama 
dengan 0 berarti variabel independen tidak berpengaruh terhadap variabel dependen (Nuraina, 2012)

\section{d. Defenisi Operasional Variabel}

Variabel-variabel yang dipergunakan dalam penelitian ini yaitukebijakan dividen $\left(\mathrm{X}_{1}\right)$, ukuran perusahaan $\left(\mathrm{X}_{2}\right)$, Investment Opportunity Set (IOS) sebagai varabel moderasi (Z) dan variabel leverage perusahaan (Y). Selanjutnya dapat diuraikan definisi operasionalnya melalui tabel berikut:

\section{Tabel 1}

Definisi Operasional Variabel

\begin{tabular}{|c|c|c|c|}
\hline Variabel & Definisi & $\begin{array}{l}\text { Pengukuran / } \\
\text { Indikator }\end{array}$ & Sumber \\
\hline $\begin{array}{l}\text { Kebijakan } \\
\text { Dividen } \\
\text { (X1) }\end{array}$ & $\begin{array}{l}\text { Kebijakan Dividen adalah salah } \\
\text { satu kebijakan yang harus diambil } \\
\text { oleh manajemen untuk } \\
\text { memutuskan apakah laba yang } \\
\text { diperoleh perusahaan selama satu } \\
\text { periode akan dibagi semua atau } \\
\text { dibagi sebagian lagi tidak dibagi } \\
\text { dalam bentuk laba ditahan }\end{array}$ & $D P R=\frac{D P S}{E P S}$ & $\begin{array}{l}\text { (Hemast } \\
\text { uti, } \\
\text { 2014) }\end{array}$ \\
\hline $\begin{array}{l}\text { Ukuran } \\
\text { Perusahaan } \\
\text { (X2) }\end{array}$ & $\begin{array}{l}\text { Ukuran perusahaan adalah suatu } \\
\text { skala dimana dapat diklasifikasikan } \\
\text { sebagai besar kecilnya perusahaan } \\
\text { dengan berbagai cara antara lain } \\
\text { dengan total aset perusahaan, log } \\
\text { size, nilai pasar saham, dan lain- } \\
\text { lain }\end{array}$ & $\begin{array}{l}\text { Size }=L_{n} \quad \text { Total } \\
\text { Asset }\end{array}$ & $\begin{array}{l}\text { (Novari } \\
\& \\
\text { Lestari. } \\
\text { 2016) }\end{array}$ \\
\hline $\begin{array}{l}\text { Leverage } \\
\text { Perusahaan } \\
\quad(\mathrm{Y})\end{array}$ & $\begin{array}{l}\text { Leverage perusahaan adalah } \\
\text { penggunaan dana yang berasal dari } \\
\text { pinjaman perusahaan dalam rangka } \\
\text { pengembangan perusahaan (assets } \\
\text { dan expansi) }\end{array}$ & $\begin{array}{l}\text { DER } \\
=\frac{\text { TotalHutang }}{\text { TotalAset }}\end{array}$ & $\begin{array}{l}\text { (Masruro } \\
\text { h et al.. } \\
2011)\end{array}$ \\
\hline $\begin{array}{l}\text { IOS } \\
(\mathrm{Z})\end{array}$ & $\begin{array}{l}\text { IOS adalah tersedianya alternatif } \\
\text { investasi di masa yang akan datang } \\
\text { bagi perusahaan }\end{array}$ & $\begin{array}{l}\text { MVEBVE } \\
=\frac{\text { LSBXHSP }}{\text { Equity }}\end{array}$ & $\begin{array}{l}\text { (Masruro } \\
\text { h et al.. } \\
2011 \text { ) }\end{array}$ \\
\hline
\end{tabular}




\section{HASIL DAN PEMBAHASAN \\ Analisis Regresi Linear dengan Variabel Moderasi \\ Tabel 2}

Hasil Uji Analisis Regresi Linear Tahap I

\begin{tabular}{|c|c|c|c|c|c|}
\hline \multirow[b]{2}{*}{ Model } & \multicolumn{2}{|c|}{$\begin{array}{l}\text { Unstandardized } \\
\text { Coefficients }\end{array}$} & \multirow{2}{*}{$\begin{array}{c}\text { Standardized } \\
\text { Coefficients } \\
\text { Beta } \\
\end{array}$} & \multirow[b]{2}{*}{ 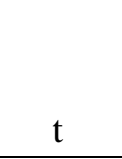 } & \multirow[b]{2}{*}{ Sig. } \\
\hline & B & Std. Error & & & \\
\hline 1 (Constant) & 15.103 & 2.902 & & 5.202 & .000 \\
\hline $\begin{array}{l}\text { Kebijakan Dividen } \\
\text { (X1) }\end{array}$ & -.0009 & .003 & -.033 & -272 & .787 \\
\hline $\begin{array}{l}\text { Ukuran Perusahaan } \\
\text { (X2) }\end{array}$ & -.508 & .103 & -.606 & -4.941 & .000 \\
\hline
\end{tabular}

Sumber: Hasil Olahan Data SPSS, 2018

Berdasarkan hasil analisis regresi linear tahap I diperoleh persamaan sebagai berikut:

1. $Y=a+\beta_{1} X_{1}+\beta_{2} X_{2}+e$

2. $Y=15,103-0,0009 X_{1}-0,508 X_{2}+e$

Persamaan regresi tahap 1 di atas dapat diartikan bahwa:

1. Nilai Konstanta yaitu 15,103 dengan parameter positif yang mana dapat disimpulkan bahwa nilai Leverage Perusahaan adalah sebesar 15,103 dengan asumsi variabel lain bernilai nol.

2. Nilai Koefisien regresi Kebijakan Dividen yaitu -0,0009 dengan parameter negatif yang mana dapat disimpulkan bahwa peningkatan satu-satuan Kebijakan Dividen maka mengakibatkan penurunan nilai koefisien Leverage Perusahaan sebesar -0,0009.

3. Nilai Koefisien regresi Ukuran Perusahaan yaitu -0,508 dengan parameter negatif yang mana dapat disimpulkan bahwa setiap peningkatan satu-satuan Ukuran Perusahaan maka akan mengakibatkan penurunan nilai koefisien Leverage Perusahaan sebesar $-0,508$. 
Tabel 3

Hasil Uji Analisis Regresi Linear Tahap II

\begin{tabular}{|c|c|c|c|c|c|}
\hline \multirow[b]{2}{*}{ Model } & \multicolumn{2}{|c|}{$\begin{array}{l}\text { Unstandardized } \\
\text { Coefficients }\end{array}$} & \multirow{2}{*}{$\begin{array}{c}\begin{array}{c}\text { Standardized } \\
\text { Coefficients }\end{array} \\
\text { Beta }\end{array}$} & \multirow[b]{2}{*}{$\mathrm{t}$} & \multirow[b]{2}{*}{ Sig. } \\
\hline & B & Std. Error & & & \\
\hline (Constant) & 15.299 & 2.975 & & 5.142 & .000 \\
\hline Kebijakan Dividen & -.001 & .004 & -.049 & -.366 & .717 \\
\hline Ukuran Perusahaan & -.516 & .106 & -.616 & -4.886 & .000 \\
\hline $\begin{array}{l}\text { Interaksi Investment } \\
\text { Opportunity Set*Kebijakan } \\
\text { Dividen }\end{array}$ & .000 & .000 & .048 & .348 & .730 \\
\hline $\begin{array}{l}\text { Interaksi Investment } \\
\text { OpportunitySet*Ukuran } \\
\text { Perusahaan }\end{array}$ & 8.230 & .000 & .059 & .463 & .646 \\
\hline
\end{tabular}

Sumber: Hasil Olahan Data SPSS, 2018

$\mathrm{Y}=\mathrm{a}+\beta_{1} \mathrm{X}_{1}+\beta_{2} \mathrm{X}_{2}+\beta_{3} \mathrm{X}_{1} * \mathrm{Z}+\beta_{4} \mathrm{X}_{2} * \mathrm{Z}$

$\mathrm{Y}=15,299+0,001 \mathrm{X}_{1}-0,516 \mathrm{X}_{2}+0,0 \mathrm{X}_{1} * \mathrm{Z}+8,230 \mathrm{X}_{2} * \mathrm{Z}$

Persamaan regresi tahap 2 di atas dapat diartikan bahwa:

1. Nilai Konstanta yaitu 15,299 dengan parameter positif yang mana dapat disimpulkan bahwa nilai Leverage Perusahaan adalah sebesar 15,103 dengan asumsi variabel lain bernilai nol.

2. Nilai Koefisien regresi interaksi antara Kebijakan Dividen dengan Investment Opportunity Set yaitu 0,0 yang mana dapat disimpulkan bahwa peningkatan satu-satuan interaksi antara Kebijakan Dividen dengan Investment Opportunity Set tidak mengalami kenaikan atau penurunan nilai koefisien Leverage Perusahaan.

3. Nilai Koefisien regresi interaksi antara Ukuran Perusahaan dengan Investment Opportunity Set yaitu 0,0 yang mana dapat disimpulkan bahwa peningkatan satu-satuan interaksi antara Ukuran Perusahaan dengan Investment Opportunity Set tidak mengalami kenaikan atau penurunan nilai koefisien Leverage Perusahaan. 
Uji Hipotesis

Uji F (Simultan)

Tabel 4

Hasil Uji Statistik F

\begin{tabular}{|c|c|c|c|c|c|}
\hline Model & $\begin{array}{l}\text { Sum of } \\
\text { Squares }\end{array}$ & $\mathrm{df}$ & Mean Square & $\mathrm{F}$ & Sig. \\
\hline Regression & 35.680 & 2 & 17.840 & 12.407 & $.000^{\mathrm{a}}$ \\
\hline
\end{tabular}

Sumber: Hasil Olahan Data SPSS, 2018

Dari tabel 4 diketahui besarnya $\mathrm{F}$ hitung yang diperoleh adalah sebesar 12,407 dengan nilai signifikansi 0,00. Dengan menggunakan tingkat $\alpha$ (Alfa) $=0,05$ atau 5\% maka disimpulkan bahwa nilai signifikansi lebih keci dari alpha $(0,00<0,05)$. Dengan demikian Kebijakan Dividen dan Ukuran Perusahaan secara simultan berpengaruh terhadap leverage Perusahaan.

Uji T (Parsial)

\section{Tabel 5}

Hasil Uji Statistik T

\begin{tabular}{|c|c|c|c|c|}
\hline \multirow[b]{2}{*}{ Model } & \multicolumn{2}{|c|}{ Tahap 1 } & \multicolumn{2}{|c|}{ Tahap 2} \\
\hline & $\mathrm{t}$ & Sig. & $\mathrm{t}$ & Sig. \\
\hline (Constanta) & 5.205 & .000 & 5.142 & .000 \\
\hline Kebijakan Dividen & -.272 & .787 & -.366 & .717 \\
\hline Ukuran Perusahaan & -4.941 & .000 & -4.886 & .000 \\
\hline $\begin{array}{l}\text { Interaksi Investment Opportunity } \\
\text { Set*Kebijakan Dividen }\end{array}$ & & & .343 & .730 \\
\hline $\begin{array}{l}\text { Interaksi Investment Opportunity } \\
\text { Set*Ukuran Perusahaan }\end{array}$ & & & .46 & .646 \\
\hline
\end{tabular}

Sumber: Hasil Olahan Data SPSS, 2018

Adapun hasil dari pengujian statistik t (uji t) pada penilitian ini adalah sebagai berikut :

1. Variabel Kebijakan Dividen $\left(X_{1}\right)$ memiliki nilai t hitung sebesar $-0,272$ dengan nilai signifikan 0,717 yaitu kecil dari taraf signifikan 0,05 (5\%). Hal ini menunjukan bahwa variabel Kebijakan Dividen $\left(\mathrm{X}_{1}\right)$ berpengaruh negatif dan tidak signifikan terhadap LeveragePerusahaan $(\mathrm{Y})$. Hasil uji $\mathrm{t}$ ini berarti menolak hipotesis 1 $\left(\mathrm{H}_{1}\right)$.

2. Variabel Ukuran Perusahaan $\left(\mathrm{X}_{2}\right)$ memiliki nilai t hitung sebesar -4.941 dengan nilai signifikan 0,000 yaitu kecil dari taraf signifikan 0,05 (5\%). Hal ini menunjukan bahwa variabel Ukuran Perusahaan(X2) berpengaruh negatif dan signifikan terhadap variabel Leverage Perusahaan (Y). Hasil uji t ini berarti menerima hipotesis $2\left(\mathrm{H}_{2}\right)$.

3. Variabel moderasi dalam penelitian ini adalah Investment Opportunity Set (Z)dengan memiliki nilai $\mathrm{t}$ hitung pada interkasiInvestment Opportunity Set $(Z)$ dengan Kebijakan Dividen (X1) sebesar 0,343 dengan nilai signifikan 0,730 yaitu besar dari 
taraf signifikan $0,05(5 \%)$. Hal ini menunjukan bahwa variabel Investment Opportunity Set $(Z)$ berpengaruh positif dan tidak signifikan terhadap hubungan antara Kebijakan Dividen (X1) dengan variabel Leverage Perusahaan (Y). Hasil uji t ini berarti menolak hipotesis $3\left(\mathrm{H}_{3}\right)$.

4. Variabel moderasi dalam penelitian ini adalah Investment Opportunity Set $(Z)$ dengan memiliki nilai t hitung pada interkasi Investment Opportunity Set (Z) dengan Ukuran Perusahaan(X2) sebesar 0,463 dengan nilai signifikan 0,646 yaitu besar dari taraf signifikan $0,05 \quad(5 \%)$. Hal ini menunjukan bahwa variabel Investment Opportunity $\operatorname{Set}(Z)$ berpengaruh positif dan tidak signifikan terhadap hubungan antara Ukuran Perusahaan(X2) dengan variabel Leverage Perusahaan (Y). Hasil uji t ini berarti menerima hipotesis $4\left(\mathrm{H}_{4}\right)$.

\section{Uji R-Square (Koefisien Determinasi)}

\section{Tabel 6}

Hasil R-Suare

\begin{tabular}{llrrr}
\hline Model & R & R Square & $\begin{array}{c}\text { Adjusted R } \\
\text { Square }\end{array}$ & $\begin{array}{c}\text { Std. Error of the } \\
\text { Estimate }\end{array}$ \\
\hline 1 & $.609^{\mathrm{a}}$ & .371 & .341 & 1.19912 \\
\hline
\end{tabular}

Sumber: Hasil Olahan Data SPSS, 2018

Berdasarkan hasil dari uji koefisien determinasi di atas dapat dilihat pada nilai Adjusted $\mathrm{R}$ Square sebesar 0,341. Hal ini menunjukan variabilitas variabel dependen dijelaskan oleh variabel independen sebesar 34,1\% atau dapat diartikan bahwa 34,1\% tingkat Leverage dipengaruhi oleh Kebijakan Dividen $\left(\mathrm{X}_{1}\right)$, dan Ukuran Perusahaan $\left(\mathrm{X}_{2}\right)$, sedangkan sisanya sebesar $65,9 \%$ dipengaruhi oleh variabel lain, yang tidak diteliti pada penelitian ini.

\section{Pembahasan}

Dari pengujian hipotesis yang telah dilakukan dengan melakukan pengujian terhadap persamaan regresi tentang pengaruh Kebijakan Dividen dan Ukuran Perusahaan terhadap Leverage, serta pengaruh Investment Opportunity Set dalam memoderasi pengaruh Kebijakan Dividen dan Ukuran Perusahaan terhadap Leverage Perusahaan. Maka hasil tersebut dapat diperoleh sebagai berikut :

Pengaruh Kebijakan Dividen terhadap Leverage Perusahaan

Hasil pengujian hipotesis yang telah dilakukan pada hipotesis 1 menunjukan bahwa variabel Kebijakan Dividen tidak berpengaruh terhadap Leverage Perusahaan, yang mana dapat diketahui nilai signifikansi yang diperoleh adalah 0,717 yaitu besar dari taraf signifikan 0,05 (5\%). Hal tersebut dapat disimpulkan bahwa Kebijakan Dividen berpengaruh negatif dan tidak signifikan terhadap Leverage Perusahaan, artinya keputusan mengenai apakah laba yang diperoleh perusahaan akan dibagikan kepada pemegang saham sebagai dividen atau diinvestasikan kembali tidak berdampak terhadap kebijakan hutang 
perusahaan, namun hal ini tergantung kepada pihak perusahaan dalam memutuskan kebijakan apa yang perlu diambil. Dengan demikian dapat dinyatakan bahwa hipotesis pertama $\left(\mathrm{H}_{1}\right)$ ditolak.

Hasil penelitian ini sesuai dengan penelitian yang telah dilakukan oleh Djabid (2009) tentang Kebijakan Dividen dan Struktur Kepemilikan Modal terhadap Kebijakan Hutang pada perusahaan manufaktur yang terdaftar di Bursa Efek Indonesia dari tahun 2004 2008 yang menyatakan bahwa Kebijakan Dividen tidak berpengaruh terhadap Kebijakan Hutang.

Pengaruh Ukuran Perusahaan terhadap Leverage Perusahaan

Hasil pengujian hipotesis yang telah dilakukan pada hipotesis 2 menunjukan bahwa variabel Ukuran Perusahaan berpengaruh terhadap Leverage, yang mana dapat diketahui nilai signifikansi yang diperoleh 0,000 yaitu kecil dari taraf signifikan 0,05 (5\%). Hal tersebut dapat disimpulkan bahwa Ukuran Perusahaan berpengaruh positif dan signifikan terhadap Leverage Perusahaan, artinya dilihat dari seberapa besar ukuran perusahaan yang diukur dengan total aset yang dimiliki oleh perusahaan akan berdampak pada kemudahan perusahaan dalam memperoleh dana eksternal yaitu hutang. Dengan demikian dapat dinyatakan bahwa hipotesis $2\left(\mathrm{H}_{2}\right)$ diterima.

Hasil penelitian ini sesuai dengan penelitian yang telah dilakukan oleh Moh. Syadeli (2013) tentang Struktur Kepemilikan, Profitabilitas dan Ukuran Perusahaan Terhadap Kebijakan Hutang pada perusahaan manufaktur yang terdaftar di Bursa Efek Indonesia dari tahun 2008 2010 menemukan bahwa Ukuran Perusahaan berpengaruh signifikan terhadap Kebijakan Hutang. Hasil yang sama ditemukan oleh Nuraina (2012) tentang Pengaruh Kepemilikan Institusional dan Ukuran Perusahaan Terhadap Kebijakan Hutang dan Nilai Perusahaan pada perusahaan manufaktur yang terdaftar di Bursa Efek Indonesia dari tahun 2006 - 2008 yang menyatakan bahwa Ukuran Perusahaan berpengaruh signifikan terhadap Kebijakan Hutang.

Pengaruh Kebijakan Dividen terhadap Leverage Perusahaan dengan Investment Opportunity Set (IOS) Sebagai Variabel Moderasi

Hasil pengujian hipotesis yang telah dilakukan pada hipotesis 3 menunjukan bahwa variabel Investment Opportunity Set tidak berpengaruh terhadap hubungan Kebijakan Dividen dengan variabel Leverage Perusahaan yang mana dapat diketahui nilai signifikansi yang diperoleh dari interaksi Investment Opportunity Set dengan Kebijakan Dividen sebesar 0,730 yaitu besar dari taraf signifikan 0,05 (5\%). Hal tersebut dapat disimpulkan bahwa Investment Opportunity Set berpengaruh positif dan tidak signifikan terhadap pengaruh terhadap Kebijakan Dividen dengan variabel Leverage Perusahaan, artinya pilihan atau kesesmpatan investasi saat ini dan diharapkan akan menghasilkan keuntungan yang lebih banyak di masa yang akan datang tidak berdampak terhadap keputusan perusahaan dalam memutuskan 
untuk menggunakan dana ekternal yaitu hutang. Dengan demikian dapat dinyatakan bahwa hipotesis $3\left(\mathrm{H}_{3}\right)$ ditolak.

Hasil penelitian ini sesuai dengan hasil penelitian yang telah dilakukan oleh Kennedy, Fitrios, \& Fitri (2009) tentang Pengaruh Dividen, Aliran Kas Bebas, Ukuran Perusahaan, Profitabilitas dan Risiko terhadap Leveragae Perusahaan pada perusahaan manufaktur yang listing di Bursa Eek Indonesia selama tahun 2017 dengan Set Kesempatan Investasi (IOS) Sebagai Variabel Moderasi menemukan bahwa Investment Opportunity Set tidak mempengaruhi hubungan antara kebijakan dividen dengan Leverage perusahaan. Hasil yang sama ditemukan oleh Masruroh, Nursanti, \& Lisa (2011) tentang Analisis Pengaruh Moderasi Investment Opportunity Set dengan Kebijakan Dividen Serta Moderasi Investment Opportunity Set dengan Arus Kas Bebas Terhadap Tingkat Leverage Perusahaan pada perusahaan makanan dan minuman yang terdaftar di Bursa Efek Indonesia dari tahun 2003 - 2007 yang menyatakan bahwa Hasil moderated regression analysis menyimpulkan bahwa kebijakan dividen tidak mempengaruhi leverage perusahaan.

Pengaruh Ukuran Perusahaan terhadap Leverage Perusahaan dengan Investment Opportunity Set (IOS) Sebagai Variabel Moderasi

Hasil pengujian hipotesis yang telah dilakukan pada hipotesis 4 menunjukan bahwa variabel Investment Opportunity Set tidak berpengaruh terhadap hubungan antara Ukuran Perusahaan dengan variabel Leverage yang mana dapat diketahui nilai signifikansi yang diperoleh dar interaksi Investment Opportunity Set dengan Ukuran Perusahaan sebesar 0,646 yaitu kecil dari taraf signifikan 0,05 (5\%). Hal tersebut dapat disimpulkan bahwa Investment Opportunity Set berpengaruh positif dan tidak signifikan terhadap hubungan antara Ukuran Perusahaan dengan variabel Leverage Perusahaan, artinya kesempatan investasi perusahaan tidak berdampak begitu besar mengenai jaminan perusahaan dalam memperoleh sejumlah dana berbentuk hutang yang dilihat pada seberapa besar total aset yang dimiliki oleh perusahaan. Dengan demikian dinyatakan bahwa hipotesis $4\left(\mathrm{H}_{4}\right)$ diterima.

Hasil penelitian ini sesuai dengan hasil penelitian yang telah dilakukan oleh Kennedy, Fitrios, \& Fitri (2009) tentang Pengaruh Dividen, Aliran Kas Bebas, Ukuran Perusahaan, Profitabilitas dan Risiko terhadap Leveragae Perusahaan dengan Set Kesempatan Investasi (IOS) Sebagai Variabel Moderasi pada perusahaan manufaktur yang listing di Bursa Eek Indonesia selama tahun 2017 dengan Set Kesempatan Investasi (IOS) Sebagai Variabel Moderasi menemukan bahwa Investment Opportunity Set tidak mempengaruhi hubungan antara kebijakan dividen dengan Leverage perusahaan. Hasil yang sama juga ditemukan oleh Rofniati (2007) tentang Analisis Moderasi Investment Opportunity Set (IOS) Terhadap Hubungan Antara 
Dividen, Aliran Kas Bebas, Ukuran Perusahaan dan Profitabilitas Dengan Tingkat Leverage Perusahaan pada perusahaan manufaktur yang terdaftar di Bursa Efek Indonesia pada tahun 2004 - 2006 bahwa IOS tidak mempengaruhi hubungan antara Ukuran Perusahaan dengan Leverage perusahaan

\section{SIMPULAN}

Dari hasil pengujian hipotesis yang telah dilakukan mengenai analisis Pengaruh Kebijakan Dividendan Ukuran Perusahaan terhadap Leverage dengan Investment Opportunity Set Sebagai Variabel Moderasi maka dapat ditarik kesimpulan sebagai berikut:

1. Variabel Kebijakan Dividenberpengaruh negatif dan tidak signifikan terhadap Leverage Perusahaan dengan nilai sig 0,717>0,05, maka hipotesis ditolak karena tidak mendukung hipotesis $1\left(\mathrm{H}_{1}\right)$ bahwa Kebijakan Dividen berpengaruh positif dan signifikan terhadap Leverage Perusahaan

2. Variabel Ukuran Perusahaan berpengaruh negatif dan signifikan terhadap Leverage dengan nilai sig $0,000<0,05$, maka hipotesis diterima karena mendukung hipotesis $2\left(\mathrm{H}_{2}\right)$ bahwa Ukuran Perusahaan berpengaruh negatif dan signifikan terhadap Leverage Perusahaan.

3. Variabel Investment Opportunity Set (IOS) berpengaruh positif dan tidak signifikan terhadap hubungan antara Kebijakan Dividen dengan Leverage Perusahaandengan nilai sig 0,730>0,05, maka hipotesis ditolak karena tidak mendukung hipotesis $3\left(\mathrm{H}_{3}\right)$ bahwa Investment Opportunity Set (IOS) berpengaruh positif dan tidak signfikan terhadap hubungan antara Kebijakan Dividen dengan Leverage Perusahaan.

4. Variabel Investment Opportunity Set (IOS) berpengaruh positif dan tdak signifikan terhadap hubungan antara Ukuran Perusahaan dengan Leverage Perusahaan dengan nilai sig 0,463> 0,05, maka hipotesis diterima karena mendukung hipotesis $3\left(\mathrm{H}_{3}\right)$ bahwa Investment Opportunity Set (IOS) berpengaruh positif dan tidak signifikan terhadap hubungan antara Kebijakan Dividen dengan Leverage Perusahaan.

\section{UCAPAN TERIMAKASIH}

Selesainya penulisan ini, penulis banyak mendapatkan bantuan dan dorongan baik secara moril maupun spiritual, oleh karena itu penulis ingin menyampaikan rasa terimakasih yang sebesar-besarnya kepada:Bapak Febryandhie Ananda, SE., Msi selaku ketua STIE"KBP" Padang, Ibu FebsriSusanti, SE., MM. selaku ketua Program Studi Manajemen, Ibu Aminar Sutra Dewi, SE., M.Si. selaku dosen pembimbing dalam membuat skripsi ini dan penulis banyak berterima kasih atas kesabaran, kepedulian dan kesempatan yang diberikan, penulis berharap kebaikan Ibu bisa dibalas oleh Tuhan Yang Maha Esa, Ibu Maria Magdalena, S.Pd., MM. selaku penasehat akademik program studi manajemen serta semua pihak yang telah banyak membantu penulis yang tidak bisa penulis sebutkan satu persatu. 


\section{DAFTAR PUSTAKA}

Afriyeni, A., \& Marlius, D. (2017). Analisis Pengaruh Harga Saham Perdana Terhadap Abnormal Return Yang Diterima Investor Studi Pada Bursa Efek Indonesia. https://doi.org/10.31219/osf.io/8z7hx

Afriyeni, A., \& Marlius, D. (2018). Analisis Pengaruh Informasi Prospektus Perusahaan Terhadap Initial Return Saham Pada Pasar Perdana Di Bursa Efek Indonesia. https://doi.org/10.31219/osf.io/kt6c4

Afriyeni, A., \& Marlius, D. (2019). Analisis Faktor-Faktor Yang Berpengaruh Terhadap Ketepatan Waktu Penyampaian Laporan Keuangan Pada Perusahaan Yang Listing Di Bursa Efek Indonesia. https://doi.org/10.31219/osf.io/rv4qf

Afriyeni, A., \& Marlius, D. (2019). Analisis Tingkat Pengembalian Dan Risiko Investasi (Studi Pada Industri Manufaktur Yang Terdaftar Di Bursa Efek Indonesia). https://doi.org/10.31219/osf.io/cfb92

Afriyeni, A., \& Fernos, J. (2019). Analisis Pengaruh Faktor Determinan Terhadap Economic Value Added Dan Implikasinya Terhadap Pergerakan Harga Saham Properti Di Bursa Efek Indonesia. https://doi.org/10.31219/osf.io/qf5nm

Arieska, M., \& Gunawan, B. (2009).Pengaruh Aliran Kas Bebas dan Keputusan Pendanaan Terhadap Nilai Pemegang Saham dengan Set Kesempatan Investasi dan Dividen Sebagai Variabel Moderasi.Akuntansi Dan Keuangan, 13(1), 13-23.

Astuti, A. P., \& Efni, Y. (2015). Pengaruh Kesempatan Investasi, Leverage Terhadap Kebijakan Deviden dan Nilai Perusahaan Pada Perusahaan Manufaktur yang Terdaftar di Bursa Efek Indonesia. Jurnal Tepak Manajemen Bisnis, VII(3), 343-356.

Djabid, A. W. (2009). Kebijakan Dividen Dan Struktur Kepemilikan Terhadap Kebijakan Utang: Sebuah Perspektif Agency Theory. Jurnal Keuangan Dan Perbankan, 13(2), 249-259.

Hemastuti, C. pami. (2014). Pengaruh Profitabilitas, Kebijakan Dividen, Kebijakan Hutang, Keputusan Investasi dan Kepemilikan Insider Terhadap Nilai Perusahaan. Jurnal Ilmu \& Riset Akuntansi, 3(4), 114.

Kennedy, Fitrios, R., \& Fitri, R. (2009). Pengaruh Dividen, Aliran Kas Bebas, Ukuran Perusahaan, Profitabilitas Dan Risiko Terhadap 
Leverage Perusahaan Dengan Set Kesempatan Investasi (IOS) Sebagai Variabel Moderating (Suatu Studi Empiris Terhadap Perusahaan Manufaktur Yang Listing di Bursa Efek. Kajian Akuntansi Dan Auditing, 4(1).

Larasati, E. (2011). Pengaruh Kepemilikan Manajerial , Kepemilikan Institusional dan Kebijakan Dividen terhadap Kebijakan Hutang Perusahaan. Ekonomi Bisnis, 16(2), 103-107.

Liputan6. (2017). Ekonom Sebut Daya Beli Masyarakat Turun, Ini Sebabnya. Retrieved from http://bisnis.liputan6.com/read/3040594/ekonom-sebut-daya-belimasyarakat-turun-ini-sebabnya

Masruroh, Nursanti, T. D., \& Lisa. (2011). Analisis Pengaruh Moderating Investment Opportunity Set Dengan Kebijakan Dividend Serta Moderating Investment Opportunity Set Dengan Arus Kas Bebas Terhadap Tingkat Leverage Perusahaan Makanan dan Minuman Yang Terdaftar di BEI Periode 2003-2007. T He WINNERS, 12(2), 121141.

Mayliza, R. (2019). Pengaruh Good Corporate Governance Dan Leverage Terhadap Kinerja Keuangan Pada Perbankan Yang Terdaftar Di BEI. https://doi.org/10.17605/OSF.IO/M9DT6

Novari, P. M., \& Lestari, P. V. (2016). Pengaruh Ukuran Perusahaan, Leverage, dan Profitabilitas Terhadap Nilai Perusahaan Pada Sektor Properti dan Real Estate. E-Jurnal Manajemen Unud, 5(9), 56715694.

Nuraina, E. (2012). Pengaruh Kepemilikan Institusional dan Ukuran Perusahaan Terhadap Kebijakan Hutang Dan Nilai Perusahaan (Studi Pada Perusahaan Manufaktur yang Terdaftar di BEI).Bisnis Dan Ekonomi, 19(2), 110-125.

Purnami, K. D. A., \& Artini, L. G. S. (2016). Pengaruh Investment Opportunity Set, Total Asset Turn Over dan Sales Growth Terhadap Kebijakan Dividen. E-Jurnal Manajemen Unud, 5(2), 1309-1337.

Rofniati, (2007), Analisis Moderasi Set Kesempatan Investasi (IOS) Terhadap Hubungan Antara Dividen, Aliran Kas Bebas, Ukuran Perusahaan Dan Profitabilitas Dengan Tingkat Leverage Perusahaan. Skripsi Fakultas Ekonomi UNRI . 
Susanto, Y. K. (2011). Kepemilikan Saham, Kebijakan Dividen, Karakteristik Perusahaan, Risiko Sistimatik, Set Peluang Investasi dan Kebijakan Hutang. Bisnis Dan Akuntansi, 13(3), 195-210.

Suwardika, I. N. A., \& Mustanda, I. K. (2017). Pengaruh Leverage, Ukuran Perusahaan, Pertumbuhan Perusahaan, dan Profitabilitas Terhadap Nilai Perusahaan Pada Perusahaan Properti. E-Jurnal Manajemen, 6(3), 1248-1277.

Syadeli, M. (2013). Struktur Kepemilikan, Profitabilitas dan Ukuran Perusahaan Terhadap Kebijakan Hutang Perusahaan Pemanufakturan di Bursa Efek Indonesia. Manajemen Dan Akuntansi, 2(2), 79-94.

Viska, V. Y., \& Dewi, A. S. (2018). Pengaruh Tingkat Inflasi, Suku Bunga Dan Nilai Kurs Dollar As Terhadap Indeks Harga Saham Gabungan Pada Bursa Efek Indonesia (BEI) Periode 2011-2015. https://doi.org/10.31219/osf.io/szfdh 